14 Literatura e Sociedade

\title{
TRANIÇC̄ES
}

\section{Iná Camargo Costa}

Universidade de São Paulo

\section{Resumo}

Pautado pelo livro de Peter Szondi, mas adotando um viés abertamente brechtiano, o texto examina peças de Ibsen, Tchekhov, Strindberg, Hauptmann, Ernst Toller e outros, buscando mostrar como Brecht resolveu no âmbito dos recursos do gênero épico a crise instaurada por Ibsen na forma do drama.

\section{Abstract}

Guided by Peter Szondis book, but adopting an openly Brechtian view, this essay examines plays by Ibsen. Tchekhov, Strindberg, Hauptmann, Ernst Toller and others, and aims to show how Brecht has resolved, in the realm of procedures of the epic genre, the crisis established by Ibsen in the form of drama.

\author{
Palavras-chave \\ Crise do drama; \\ drama naturalista; \\ teatro político e \\ teatro épico.
}

\section{Keywords}

Crisis of drama; naturalist drama; political theatre and epic theatre. 
esde que Ibsen fez a dramaturgia do século XIX começar a narrar, instaurou-se uma espécie de guerra civil não declarada na cena e na crítica. Na cena, além da censura oficial que proibia uma infindável coleção de assuntos, os próprios empresários e elencos rejeitavam com vários graus de resistência os novos experimentos dramatúrgicos. E, quando não o faziam e se dispunham a correr os riscos, seus próprios hábitos e técnicas pautados pela sedimentação dos pressupostos dramáticos inviabilizavam os experimentos. Os resultados deixavam todos os envolvidos infelizes: os dramaturgos, porque viam seus textos literalmente destruídos; os elencos, porque se frustravam com os desastres; e os produtores, por causa dos prejuízos com a bilheteria.

Quanto aos críticos, ainda mais empenhados na preservação de seus saberes e, como dizia Antoine, com uma disposição quase instintiva para preservar os interesses estéticos de seus clientes burgueses, esses travaram uma luta sem quartel contra aquilo que identificavam como o risco de "destruição do teatro" e de seus valores eternos.

A consequência disso foi a produção de quantidades industriais de incompreensão do que se passava na cena e sobretudo na dramaturgia. Foi preciso esperar o aparecimento de um pesquisador como Peter Szondi, já na segunda metade do século XX, para que fosse lançada alguma luz sobre o que ele chamou de "crise do drama moderno".

O texto que segue se pauta basicamente por suas reflexões, mas se desenvolve numa perspectiva mais específica, pois aqui o horizonte é a dramaturgia brechtiana.

\section{Ibsen, Tchekhov e a crise do drama moderno}

\section{Ibsen}

Durante o século XIX, o drama alcançou um grau de hegemonia de tal ordem que passou a ser sinônimo de teatro. Sua expressão degradada, transformada em 
receita na França por volta de 1820, é a chamada peça-bem-feita, que depois serviu de modelo para os estúdios de Hollywood na primeira década do século XX e até hoje é ensinada em manuais de roteiros.

De acordo com Peter Szondi, ${ }^{1}$ um dos primeiros abalos impostos à forma foi obra de Ibsen, dramaturgo norueguês que durante uns bons vinte anos esforçouse para escrever segundo a receita. Ele já era um dramaturgo consagrado, encenado em toda a Europa, quando produziu a primeira obra que, além de se transformar em escândalo e sofrer censura em mais de um país, punha em questão a ideia de universalidade do indivíduo livre, o mais importante dos pressupostos do drama, ainda que de maneira pouco perceptível para a época, por se restringir ao âmbito temático. A peça em questão, Casa de boneca, encenada em 1879, demonstrou de maneira cabal (e crítica) que a ideia burguesa de liberdade humana excluía no mínimo a metade feminina dessa humanidade. Por isso a peça é muito justamente considerada um divisor de águas na obra de Ibsen. A tal ponto que suas peças anteriores passaram a ter interesse apenas para fins de pesquisa, com a provável exceção de Peer Gynt e, mesmo essa, mais por razões musicais (por causa do balé composto por Grieg) do que dramáticas.

Em Casa de boneca temos a história de Nora, casada com Torvald Helmer, três filhos, que decide abandoná-lo quando se descobre uma perfeita mulher da sociedade burguesa, isto é, uma boneca, sem nenhum direito, primeiro dependente do pai e depois, do marido - que ostensivamente tinha com ela uma relação paternal. Sua decisão de abandonar esse papel e sair de casa em busca de liberdade e direitos foi tão chocante para a época que, na Alemanha, por exemplo, o dramaturgo foi obrigado pela censura a dar outro desfecho à peça. Em compensação, o dramaturgo recebeu inúmeras homenagens do movimento feminista (então vinculado ao socialista) em vários países, e, de um modo geral, foram mulheres que primeiro traduziram sua peça para outras línguas, como Eleanor Marx-Aveling, para o inglês.

A partir de Casa de boneca, até sua última peça, Quando despertamos de entre os mortos, Ibsen progressivamente porá em crise outros elementos formais do drama, com especial ênfase à proibição do flashback. Isso é o mesmo que dizer, como já fez Peter Szondi, que com Ibsen o drama começou a narrar, a se interessar pelo passado e, por isso, houve quem classificasse suas peças de dramas analíticos, procurando associá-las, por exemplo, ao Édipo de Sófocles, como veremos adiante. De acordo com a teoria dos gêneros, a essa altura mobilizada em caráter normativo, só o épico tem acesso ao passado e a forma que lhe correspondia era o romance (também sinônimo de "literatura", assim como o drama era sinônimo de "teatro"). Por esses critérios conservadores, não era difícil de perceber que Ibsen, mesmo fazendo teatro, se voltava para interesses mais próprios do romance e que no seu horizonte estava o gênero épico.

Esse interesse ainda não está muito claro em Casa de boneca, porque seu desfecho contém uma pergunta pelo futuro de Nora e mesmo de sua família burguesa abandonada (Torvald Helmer agora é diretor de um grande banco, um executivo

\footnotetext{
${ }^{1}$ Peter Szondi, Teoria do drama moderno, São Paulo, Cosac \& Naify, 2001.
} 
na linguagem mais atual e menos hipócrita que a do século passado). Mas a partir da peça seguinte, Os espectros (1881), Ibsen começa a matar ou a enlouquecer seus personagens, sempre como castigo por terem feito o jogo da sociedade burguesa no passado que as peças reconstituem - casamentos por interesse, mentiras e hipocrisia em nome das conveniências etc.

Com Os espectros, Ibsen passou a ser considerado um "companheiro de viagem" do naturalismo, não apenas por sua temática de caráter cientificista (herança genética), mas sobretudo por se tratar de peça censurada que só poderia mesmo ser encenada num teatro livre (e, mesmo assim, na França o teatro que a encenou esteve ameaçado de interdição).

Tematicamente precedendo Solness, e encenada em 1877, Os pilares da sociedade conta a história de um comerciante muito rico e muito prestigiado na cidade, mas de passado obscuro. Ele era dado a práticas criminosas, mas nada excepcionais, como a do suborno e a de fazer contratos com navios sabidamente avariados para, depois do desastre premeditado, receber o seguro marítimo (sem se importar, evidentemente, com detalhes como as mortes que um naufrágio provoca). Numa cerimônia em que é homenageado, sua cunhada o desmascara e ele faz uma confissão pública, com direito a perdão. Mas aqui ainda estamos diante de uma situação técnica em que o passado condena de maneira dramática.

Com Os espectros, a crítica da época entendeu que Ibsen teria achado o caminho da tragédia moderna, pois, ao definir o destino de seu personagem por meio da herança genética, inteiramente fora do controle humano, o dramaturgo descobrira para o teatro moderno um modo de reintroduzir a própria noção de destino e de fatalidade, essencial ao conceito de tragédia. Por esse prisma, o herói da peça seria Helena Alving, que, ao descobrir a sífilis do marido, teria tentado abandoná-lo, mas foi convencida pelo pastor a não o fazer. O resultado é o nascimento do filho que ficará louco quando adulto. Otto Maria Carpeaux resume assim essa opinião da crítica mais avançada:

O verdadeiro herói de Os espectros é Helena Alving: culpada ativa e vítima passiva em uma pessoa. Essa mãe é da estirpe dos Édipos, das Antígonas, das grandes figuras da tragédia grega. A própria peça, guardando rigorosamente as três unidades da ação, do tempo e do espaço, é uma tragédia clássica. A maior tragédia do teatro moderno. ${ }^{2}$

A possibilidade de entender essa peça por um prisma materialista foi demonstrada por Brecht em uma crítica fulminante: trata-se da história de uma mulher que casou por dinheiro e passou toda a vida cultivando mentiras; no final, as mentiras custaram muito caro e deu tudo errado, pois elas foram descobertas e a situação ficou ainda pior. ${ }^{3}$

\footnotetext{
${ }^{2}$ Otto Maria Carpeaux, "Ensaio sobre Henrik Ibsen", in Henrik Ibsen, Seis dramas, Rio de Janeiro, Ediouro, s. d., p. 41.

${ }^{3}$ Bertolt Brecht, "Les revenants, d'Ibsen", in Ecrits sur le théâtre, Paris, L'Arche, 1972, v. 1, p. $10-11$.
} 
Quanto a Solness, uma forma de associá-la à tragédia clássica, particularmente ao Édipo, decorre da identificação de sua estrutura como drama analítico: a história já começa no fim da vida do "herói" (ele está velho); os incidentes servem para passar sua vida a limpo e, após as últimas e mais graves acusações, ele morre - mais ou menos com o mesmo grau de deliberação que levou Édipo a furar os próprios olhos. Mas uma leitura mais detida da peça pode levar a outras conclusões.

Solness é um construtor (meio-engenheiro, meio-arquiteto) muito esperto e inteligente o suficiente para perceber que na profissão (como projetista) quando muito é medíocre. Mas ele se tornou célebre porque soube explorar com método a criatividade de dois de seus empregados, pai e filho. Ele sabe que o jovem Ragnar é um gênio, mas, felizmente para ele, sem consciência do próprio valor. Seu objetivo, nesse caso, é mantê-lo como empregado em seu escritório. Não economiza meios para isso e o que temos oportunidade de ver no primeiro ato é o modo como envolve Kaia - noiva do rapaz, mas apaixonada por Solness -, fazendo-a acreditar que precisa dela a seu lado. Por Knut Brovik (pai de Ragnar, que está muito doente) ficamos sabendo que Solness começou a vida profissional como seu empregado e então não entendia grande coisa do ofício. Mas Solness subiu na vida esmagando muita gente, ele incluído - mais adiante saberemos como e a que preço. Ainda nesse primeiro ato aparece uma pista sobre a origem da fortuna de Solness: um incêndio que destruiu a casa herdada dos pais de sua mulher. Fica também sugerido que na mesma ocasião, sua esposa Aline, doente dos nervos, sofreu um outro golpe além desse.

Esse ato se encerra com a chegada de uma jovem, Hilda Wangel, que conheceu o casal dez anos antes na festa de inauguração de uma torre que fora restaurada por Solness. Ela é uma espécie de precursora dos hippies: tem vinte e poucos anos, saiu de casa com uma mochila nas costas, sem dinheiro e sem planos. Chegou ali porque foi convidada por Aline Solness quando ambas estavam internadas em um sanatório. Não sabe quanto tempo vai ficar.

Hilda se lembra de coisas que aconteceram, como a inauguração, em que ficou fascinada com a figura do construtor no alto da torre, depositando uma coroa de flores, como era o costume. Mas também se "lembra" do que não aconteceu, como o beijo que teria recebido de Solness e sua promessa de fazer uma torre para ela. Solness deixa a ilusão prosperar, concluindo que a moça lhe dava a energia de que precisava para enfrentar a mocidade (já sabemos quem).

No segundo ato, as reminiscências assumirão um tom mais pesado e sombrio. É então que ficamos sabendo que o casal teve gêmeos que só viveram quinze dias. As histórias se juntam: a casa que está sendo construída fica no terreno da que se queimou; o incêndio aconteceu logo depois do nascimento das crianças; em consequência dele, Aline teve uma febre, mas assim mesmo continuou amamentando os filhos, que por sua vez morreram "envenenados" pelo leite da mãe. Quanto a Solness, loteou o terreno, construiu vilas e enriqueceu, porque renunciou a ter um lar e assim se compensou pela moléstia da mulher.

$\mathrm{Na}$ conversa com Hilda, ele esclarece a sua responsabilidade pelo incêndio: sabia da existência de uma fenda na chaminé, não preveniu ninguém, nem providenciou o conserto. Ele acreditava que a sorte poderia lhe chegar por aquela fenda. Hilda acha tudo emocionante e Solness se entusiasma: 
Eu queria que aquilo acontecesse no inverno... um pouco antes do meio dia. Nessa hora, Aline e eu estaríamos fora. [...] Em casa, os criados teriam acendido um bom fogo [...] apenas chegados à porta do jardim, toda a barraca já estaria em chamas [...] Eis como eu queria que que a coisa viesse. ${ }^{4}$

Com a mesma placidez com que assume essa responsabilidade, explica que arruinou Knut Brovik e por essa razão não pode permitir que Ragnar tenha sucesso, caso em que esse poderá fazer o mesmo com ele, isto é, destruí-lo, derrubá-lo. Esse ato termina com o anúncio da inauguração da casa e da colocação das flores na torre. Aline avisa que Solness sofre de vertigens.

Enquanto esperam pela inauguração, Hilda e Aline conversam. Ficamos então sabendo que Aline se conformou com a morte dos filhos, pois afinal foi obra da Providência, não há o que lamentar. O que ela não pode aceitar e constitui a verdadeira causa do seu sofrimento é a perda, no incêndio, de suas coisas: retratos, vestidos, rendas e... suas noventa e uma bonecas! Todo o ato se constrói em função do suspense anunciado: Solness subirá à torre ou não? Forma-se uma multidão; Hilda, cada vez mais exaltada, relata a subida de Solness por meio da técnica da teicoscopia. ${ }^{5}$ Ibsen toma a palavra e descreve o desfecho na rubrica:

As senhoras, de pé, na varanda, agitam seus lenços. Ouvem-se vivas! na rua. Subitamente se faz silêncio, depois a multidão lança um grito de terror. Entrevê-se indistintamente por entre as árvores a queda de um corpo humano, que cai entre as vigas e tábuas. Aline desmaia, o médico vai correndo em direção ao local da queda e Hilda parece ter enlouquecido de vez: fica repetindo "meu mestre, meu mestre!

A aproximação dessa peça com o Édipo é estruturalmente justificada, pois em ambas temos a progressiva reconstituição do passado que tem uma catástrofe por desfecho - cegueira de Édipo e morte de Solness. Pode-se também avançar na interpretação da morte de Solness como uma espécie de autopunição equivalente à de Édipo. Mas, bem pesadas as situações, veremos que Ibsen está tratando de coisa bem diferente de Sófocles.

Antes de mais nada, é bom verificar que, ao contrário do que se passa em Édipo, onde as revelações são objetivas, isto é, todos sabem quais são os crimes e só falta saber quem os cometeu, o que efetivamente ocorre, em Solness elas não ultrapassam o campo da subjetividade. As "confissões" do empreendedor são feitas apenas a Hilda e por seu intermédio nós, o público, também ficamos sabendo delas. Assim se, ao estimular o velho com vertigens a cometer a loucura de subir à torre, Hilda cumpre, meio inconscientemente, o papel de justiceira, de maneira alguma essa informação chega aos demais personagens. Por isso não se pode atribuir à morte de Solness a mesma objetividade que tem a cegueira de Édipo.

${ }^{4}$ Henrik Ibsen, Seis dramas, Rio de Janeiro, Ediouro, s. d., p. 375.

${ }_{5}^{5}$ Tão antiga quanto a Ilíada de Homero, essa técnica narrativa para relatar o que se passa no presente fora da cena significa literalmente "olhar além do muro". Sempre foi usada no drama para relatos de ocorrências não dramáticas, ou "não encenáveis" como batalhas, catástrofes da natureza etc.

${ }^{6}$ Ibsen, Seis dramas, op. cit., p. 396. 
Como observa Peter Szondi, para entender o Édipo de Sófocles é preciso lembrar que Ésquilo também tinha uma trilogia sobre o caso (perdida) e, portanto, já se dispunha de um relato cronológico sobre o destino de Édipo. Nas suas palavras:

\begin{abstract}
Sófocles podia se basear numa apresentação épica de eventos amplamente separados no tempo porque seu problema tinha menos a ver com os eventos em si do que com a sua qualidade trágica. Esta tragédia não está presa a detalhes; ela está acima do fluxo temporal. A trágica dialética da visão e da cegueira - na qual um homem fica cego por causa do auto-conhecimento, através daquele olho "adicional" que ele tem - esta peripécia só precisa de um único ato de reconhecimento (anagnorisis) para se tornar uma realidade dramática. O espectador ateniense conhecia o mito; ele não precisa ser encenado. A única pessoa que ainda tem que passar por essa experiência é o próprio Édipo. E ele só pode fazer isso no final, depois que o mito se tornou a sua vida. A exposição aqui é desnecessária, e a análise é sinônimo de ação. Édipo, cego embora enxergue, cria, por assim dizer, o centro vazio de um mundo que já conhece o seu destino. Passo a passo, mensageiros deste mundo invadem seu ser interior e o preenchem com sua horrível verdade. Não é uma verdade confinada ao passado, que é revelado. Édipo é o assassino do pai, o marido da mãe e o irmão dos seus filhos. Ele é o "mal da terra" e só precisa saber do que aconteceu para reconhecer o que é. Portanto, a ação em Édipo rei, ainda que de fato comece antes da tragédia, está contida em seu presente. A técnica analítica em Sófocles é requerida pela própria matéria e não para reproduzir uma forma pré-existente, mas para mostrar a sua qualidade trágica na máxima pureza e profundidade. ${ }^{7}$
\end{abstract}

Nada disso se passa com Solness, a começar pela diferente concepção de destino. Enquanto Édipo não conseguiu fugir à deliberação dos deuses, Solness forjou o seu próprio destino, contra suas limitações pessoais, econômicas e sociais. Enquanto a matéria do Édipo é dramática e trágica, a de Solness é épica - está circunscrita ao passado e permanece subjetiva. Aqui ninguém fica sabendo que o incêndio não foi acidental, ninguém tem acesso às motivações (que a fresta da chaminé era conhecida de Solness, que Aline sofria pela perda de suas coisas). Em consequência, o desfecho, objetivamente, é inteiramente acidental. Tanto ocorreu como poderia não ter ocorrido. E, finalmente, como a temática (as motivações) permanece na esfera da interioridade, é impossível dar a ela apresentação dramática direta. Como diz Szondi, esse material tem necessidade da técnica analítica. Como no romance, só pode ser encenado por meio dessa técnica. E ainda assim a temática continua não encenada, ela é relatada. Esse é o problema formal básico da dramaturgia de Ibsen e por isso ele escreveu o primeiro capítulo da crise do drama.

Na sua penúltima peça, João Gabriel Borkman (1906), todos os motivos tratados anteriormente se associam ao mais revelador deles: o "herói" fracassa justamente porque aderiu de maneira radical ao jogo da especulação financeira, quebrando o banco onde trabalhava e levando à ruína sua própria família, muitos conhecidos que nele confiaram, sem falar na grande massa dos investidores. Para Borkman, todo o processo que protagonizou nada mais era do que a manifestação de sua infinita ousadia e livre iniciativa - tão nietzschianamente livre que nem às

${ }^{7}$ Szondi, Teoria do drama moderno, op. cit., p. 43-4. 
regras do banco se sujeitava. Denunciado em pleno voo especulativo, sua queda resultou em prisão de cinco anos e mais oito de reclusão deliberada, pois a vergonha não lhe permitia encarar os conhecidos. O desfecho da combinação desse feito de dimensões épicas - devidamente reconstituído por técnicas épicas - e das mesquinharias da hipocrisia em família é a morte igualmente mesquinha do personagem, inteiramente destituído de perspectivas. Nem é preciso dizer que essa peça, talvez a obra-prima de Ibsen, nunca foi encenada no Brasil e mesmo na Europa foi muito cerceada pela censura (na Alemanha especialmente).

Naquilo que nos interessa agora, sua marca principal é a radicalidade com que se volta para o passado. A perspectiva de futuro é inteiramente secundária e só diz respeito ao filho de Borkman que, como Nora Helmer, abandona a família e, mais radical que ela, vai-se embora do próprio país (como aliás o próprio Ibsen fez a certa altura da vida). Aqui o diálogo é inteiramente desdramatizado, pois sua função é estritamente rememorativa. O tempo, embora tecnicamente seja o presente do diálogo, é o tempo da memória. Todos os participantes dessa conversa em cinco atos estão interessados em compreender o passado e, se possível, convencer os seus interlocutores de que fizeram a coisa certa. Na medida em que só reafirmam as suas opções, são condenados à solidão (esposa), à doença (cunhada) e à morte (Borkman).

\section{Tchekhov}

Na peça As três irmãs (1900), Tchekhov dá um passo adiante na crise formal iniciada por Ibsen. Enquanto o norueguês esvaziou o diálogo da função dramática (impregnando-o da função épica), o russo questionou a sua função dramática. Olga, Irina e Masha são as três irmãs Prozorovas. Elas vivem com o irmão Andrei numa cidadezinha do interior da Rússia para onde se mudaram onze anos antes, acompanhando o pai que ali assumira o comando de um regimento militar. Como faz um ano que esse morreu, elas não têm mais motivo para permanecer ali (mas também não têm meios de sair), e passam o tempo todo sonhando com a volta a Moscou, lembrando dos bons tempos que lá viveram. A casa é frequentada pelos oficiais do regimento que são amigos das moças e por ocasião dessas visitas a conversa corre solta. Entre os acontecimentos cotidianos, Andrei se casa com Natasha que, ao longo da peça, vai tomando todo o espaço da residência (numa narrativa muda muito eloquente). Após algumas peripécias, como um incêndio de grandes proporções e um duelo no qual morre o noivo de Irina, o regimento se retira da cidade deixando as irmãs para trás.

Esse resumo procurou explicitar o fato de que a peça tem pouco mais do que os rudimentos de uma ação dramática no sentido que já podemos chamar de tradicional. Na verdade, o que temos em cena são apenas lembranças, sonhos, desilusões, espelhamentos e resultados. Todos os acontecimentos se dão fora de cena: casamentos, nascimentos, mortes, traições, paixões, situações de trabalho, o incêndio e o duelo. A única ação (em sentido dramático) é a história do casamento de Andrei e Natasha que, entretanto, só é apresentada em seus efeitos, produzindo uma trajetória ascendente de Natasha (de rejeitada pelas cunhadas a senhora de 
todo o espaço) e uma trajetória descendente de Andrei (de medíocre funcionário da municipalidade a viciado em jogo que hipotecou a casa para pagar dívidas).

Com exceção da quase muda Natasha (que cuida dos seus interesses), todos os personagens renunciaram ao presente: vivem de lembranças do passado e sonham com um futuro que não vem. Uma renúncia dessa ordem tem que necessariamente produzir efeitos sobre uma forma em que ficou sedimentada toda a fé renascentista no aqui e agora e nas relações interpessoais. Esses efeitos aparecem na ação e no diálogo, as mais importantes categorias formais do drama.

Como ficou dito, a peça apresenta apenas rudimentos de uma ação dramática, sem muita conexão no sentido dramático (lei da causalidade). Esses rudimentos de ação servem antes de pretexto para o que realmente interessa no teatro de Tchekhov: o diálogo, que, por sua vez, dada a situação que o determina, também não tem peso ou função dramática. O diálogo em Tchekhov é conversa monológica e nela se concentra o significado de seu teatro.

Como explica Peter Szondi (que estamos resumindo), conversa monológica é inteiramente diversa de monólogo. Tomando o exemplo clássico de Hamlet, ali o "ser ou não ser" é necessário solilóquio porque, entre outros motivos objetivos na peça, ninguém pode saber de seus planos de vingança, mas o público sim. Em As três irmãs, é conversando que os personagens se isolam. Esvaziado de sua função dramática, que é estabelecer as relações interpessoais, o diálogo se transforma essencialmente em monólogo e, com isso, o drama sai do seu elemento (diálogo) tomando o rumo do gênero lírico. O que temos nessa peça é o constante movimento da conversa em direção à lírica da solidão. Mas na maior parte do tempo, a aparência de diálogo fica preservada porque nessa conversa podemos ver como um personagem participa da solidão do outro, ou como a solidão individual participa de uma crescente solidão coletiva. É isso que impede a dissolução da forma dramática, mas ao mesmo tempo verificamos que essa chegou a seu limite, encenado e tematizado pelos personagens Andrei e Ferapont.

Andrei é o único personagem incapaz de participar daquela conversação. Sua solidão o leva ao isolamento e ao silêncio. Ele evita qualquer companhia. Só se permite falar quando sabe que não será entendido. É esse o pressuposto da cena em que Andrei estabelece com Ferapont um diálogo de surdos sem nenhuma comicidade. Como se sabe, o "diálogo de surdos" é um lugar-comum milenar da comédia, técnica que produziu um sem número de divertidíssimos quiproquós. Mas aqui, Ferapont é quase surdo mesmo, e, segundo a regra geral da peça, o que ele deixa de ouvir não produz nenhum efeito na cena. Quanto a Andrei, esse explicita a razão de seu procedimento: "Se não ouvisse mal, irmãozinho, eu não conversaria com você. Eu preciso conversar com alguém, mas minha mulher não me entende e minhas irmãs ririam de mim".

Nessa cena temos, assim, dois discursos monológicos radicais, tematicamente apoiados no motivo da surdez. Essa radicalização os contrapõe aos demais monólogos das outras conversas nas quais está sempre presente a possibilidade de entendimento (intercâmbio inter-humano). Mas entre Andrei e Ferapont, a impossibilidade é expressa temática e formalmente: trata-se do colapso da comunicação. Como a inviabilização formal do diálogo conduz necessariamente ao épico, Peter 
Szondi pode dizer que "a surdez de Ferapont aponta para o futuro" (da dramaturgia a que interessa continuar tratando dos problemas humanos do seu tempo).

Desde que se candidatou à modernização, o teatro brasileiro sempre teve dificuldades para lidar com Tchekhov, tanto na cena como na crítica. Dona Gilda de Mello e Souza explicou as razões desse fenômeno em ensaio da década de 1950: desprovidos de ação dramática e personagens de exceção, os textos de Tchekhov correm o tempo todo o risco de cair na monotonia. Os monólogos desencontrados, travestidos de diálogos, a técnica fragmentada, a nostalgia e a melancolia dos personagens que constituem uma galeria de vencidos, expondo vários graus de derrota ou frustrações, presos ao passado ou sonhando com um futuro irrealizável são os ingredientes que dificultam a direção, a interpretação e a recepção de Tchekhov entre nós, habituados a contrastes vivos e de fácil apreensão, porque apoiados em situações de conflito claramente delineados (os ingredientes do drama). ${ }^{9}$

O desafio, segundo o próprio dramaturgo que é citado por Gilda, é compreender que "para aqueles que não têm objetivos imediatos ou remotos só resta na alma um grande vazio". ${ }^{10}$ A essa percepção não faltou um adepto das conclusões taxativas de Lukács para acrescentar que, como Ibsen, Tchekhov percebeu e mostrou em seu teatro que esse tipo de gente estava condenado pela história, assim como a forma que cristalizou a ideologia de seus antepassados.

\section{Teatro livre e naturalismo: Antoine e Hauptmann}

Com Ibsen e Tchekhov, vimos como a forma do drama entrou em crise pelo simples fato de que, procurando observar e configurar na cena o comportamento de satélites da burguesia (ou pequenos burgueses, como os chamou Gorki), esses dramaturgos acabaram questionando os pressupostos da forma do drama (liberdade, conquista de objetivos) e esvaziando suas principais categorias formais (ação e diálogo). Em ambos o futuro inexiste, ou melhor, o presente é vazio e as ocorrências desse agora não forjam futuro nenhum, até porque esses personagens não são senhores de seu próprio destino. Se em Ibsen o diálogo se transformou em relato, inteiramente comprometido com a reconstituição e tentativa de justificação do passado, explicitando a matéria romanesca e a vocação épica do dramaturgo, em Tchekhov essa categoria se transformou em monólogo travestido de diálogo, explicitando a solidão e a ausência de comunicação até chegar ao impasse - a falência total das relações inter-humanas, apontando para a possibilidade de sua superação no âmbito do gênero épico.

\section{Antecedentes históricos}

O Segundo Império francês, o mais legítimo resultado dos massacres parisienses de julho de 1848, impôs ao teatro (às artes, à literatura, à imprensa) um dos

\footnotetext{
${ }^{8}$ Idem, ibidem, p. 53.

${ }^{9}$ Gilda de Mello e Souza, Exercícios de leitura, São Paulo, Duas Cidades, 1980, p. 131-136.

${ }^{10}$ Idem, ibidem.
} 
mais ferozes e bem-sucedidos sistemas de censura de que se tem notícia. A dramaturgia realista, do Alexandre Dumas Filho de A dama das camélias (1852) ao Émile Augier de As leoas pobres (1858), é a expressão legitimista desse período que se encerrou com a guerra franco-prussiana (uma das origens da primeira Guerra Mundial) e com a Comuna de Paris. Sobre a eficácia do sistema de censura ao teatro, basta lembrar que o mesmo Émile Augier aqui referido acumulava as funções de dramaturgo prestigiado e censor. No teatro realista, portanto, as convenções do drama degradadas na fórmula da peça-bem-feita são consagradas pelo público, pela crítica e asseguradas pelo Estado.

No campo dos derrotados de 1848, ou simpatizantes de sua causa, encontravam-se escritores como Baudelaire, Flaubert e Zola. Foi este um dos primeiros a mostrar, logo depois da Comuna de Paris, mais precisamente em 1873, um dos caminhos que o teatro poderia seguir entre os escombros que restaram do teatro realista e similares. Sua contribuição prática foi a adaptação para a cena de seu romance Teresa Raquin e, no plano da crítica, foi o autor dos primeiros "manifestos" do teatro naturalista.

A Terceira República - proclamada em Versalhes porque em Paris havia uma revolução em andamento -, para deixar bem claro o seu compromisso com a política "social" de Luís Bonaparte, como primeira providência diplomática, combinou com o exército prussiano a melhor estratégia para massacrar os operários parisienses, que haviam se assenhoreado da cidade abandonada.

Depois que os ânimos se acalmaram, no âmbito teatral, o elo com o regime apeado foi a manutenção e o aperfeiçoamento do eficiente sistema de censura herdado, de modo que por algum tempo os esforços de Zola e outros, como os irmãos Goncourt, continuavam cerceados a ferro e a fogo.

\section{Teatro Livre}

André Antoine aparece nesse cenário. Tratava-se de um funcionário da Companhia de Gás, apaixonado por teatro a ponto de prestar serviços de claque e figuração na Comédie Française desde muito jovem. Acabou se envolvendo em um grupo de teatro amador com mais alguns companheiros de trabalho e em breve tempo começou a encenar as peças proibidas pela censura (que não alcançava os grupos amadores), mas interessantes para ele e seu público de trabalhadores e amigos. As portas do teatro comercial estavam evidentemente fechadas para uma companhia que não dispunha de capital e contava com um repertório que a censura pusera no índex ou peças que já tinham sido recusadas pelos teatros convencionais.

As dificuldades econômicas do grupo amador (Círculo Gaulês) e a descoberta de um teatrinho desativado em Montmartre levaram à fundação do Teatro Livre, solução para a maioria dos problemas: criava-se uma associação de artistas e público (amigos e simpatizantes) que, por meio de assinaturas, garantia o financiamento das produções programaticamente baratas; por se tratar de sociedade fechada (como o grupo amador), as peças a serem encenadas não dependiam de aprovação da censura. Essa é a essência política e econômica do Teatro Livre: liberdade na escolha dos textos e liberdade em relação às convenções estéticas e 
econômicas da peça-bem-feita (ou do teatro realista). É, pois, emblemática a escolha do texto com que estreou o Teatro Livre em 1887: Jacques Damour, adaptação por Léon Hennique do conto de Zola sobre a história de um veterano da Comuna de Paris que, tendo escapado ao massacre, mas dado por morto, volta à cidade, encontra a família destruída e, depois de algumas peripécias extremamente dolorosas, vai trabalhar como caseiro para a filha que se tornou prostituta (como Naná, personagem do romance de mesmo nome).

Essas condições econômicas, estéticas e políticas explicam por que o Teatro Livre foi o introdutor na cena francesa de dramaturgos como Ibsen, Hauptmann e Strindberg - os mais relevantes expoentes da dramaturgia naturalista não francesa. E, entre os franceses que experimentavam novos caminhos como Zola, vale a pena destacar Henri Becque (Os corvos, A parisiense), que já conhecia tanto o desencontro entre as convenções do teatro realista e sua dramaturgia (o Odéon produziu sua peça Os corvos que fracassou), quanto os muito eficientes métodos e critérios de censura dos empresários teatrais (A parisiense foi recusada pelo mesmo Odéon por causa do fracasso da primeira).

Do ponto de vista formal, o que distingue peças como as de Henri Becque do repertório realista habitual é especialmente aquilo que os críticos contemporâneos (como Sarcey) chamavam de inapetência dramática: diálogos com função épica (comentários, relatos); ação pouco relevante quando não propriamente inexistente (prejudicando o ritmo) e personagens desprovidos de caráter dramático (não eram heróis burgueses, até porque provenientes das camadas sociais inferiores). Uma outra marca desse teatro foi a progressiva incorporação à cena de conjuntos cada vez mais numerosos de personagens (ensembles), contrariando abertamente uma das mais insistentes recomendações da crítica (e dos produtores, por razões salariais óbvias): restringir o número de personagens ao estritamente essencial para o bom andamento da ação dramática.

Antoine experimentou produzir o "efeito ensemble", ou efeito de multidão, pela primeira vez, em 1889. Foi com a peça A pátria em perigo, dos irmãos Goncourt, que ficara retida pela censura desde 1866. Como o próprio diretor relata em Mes souvenirs sur le Théatre-Libre (1921), a cena de protesto popular diante da prefeitura de Verdun foi a principal razão do seu interesse em encenar a peça. E seu empenho também se explica pelas convicções políticas dos militantes do Teatro Livre (que iam do republicanismo ao anarquismo, passando pelo próprio socialismo). Por isso não demorou muito tempo para a dramaturgia naturalista apresentar uma peça inteiramente inspirada num episódio histórico das lutas dos trabalhadores.

\section{Hauptmann}

A criação do Teatro Livre em Paris funcionou como uma espécie de fogo em palha seca. Pouco tempo depois, quase todos os países europeus tinham empreendimentos teatrais similares, dos quais os mais famosos são os de Berlim, Moscou, Londres e Dublin (que existe até hoje). Para se ter ideia da extensão do fenômeno, basta mencionar que Lukács aos dezoito anos foi um dos fundadores do teatro livre de Budapeste, chamado Companhia Talia. De todos esses grupos, interessa agora o 
de Otto Brahm, que em 1889 fundou a Cena Livre de Berlim lançando o dramaturgo Gerhart Hauptmann. Como se pode imaginar, no Império alemão a censura ao teatro era ainda mais feroz que a francesa, de modo que a motivação dos naturalistas alemães para viabilizar um teatro que escapasse às suas restrições era ainda maior.

Essa é a principal razão por que Os tecelões de Hauptmann estreou em Paris apenas três meses depois de Berlim. É que nessa cidade a polícia imperial não respeitou as garantias legais da Cena Livre. Em vista da repercussão que teve a peça, tratou de proibi-la em qualquer circunstância e de garantir que não mais seria encenada em território alemão. Até por uma questão de solidariedade política, o grupo de Antoine tratou de providenciar a tradução da peça e estreá-la em Paris, o que aconteceu em maio de 1893 - sob todo tipo de ameaças, diga-se de passagem, inclusive de interdição do teatro. Para além da questão política, Antoine tinha um interesse experimental por essa peça: nela havia mais de uma oportunidade de criar cenas de multidão no palco.

Embora Os tecelões já esteja bem distante da forma do drama, Hauptmann ainda se encontra preso a algumas das expectativas dramáticas, em particular a da unidade de ação, de modo que nessa peça é possível perceber uma espécie de luta entre forma (dramática) e conteúdo (épico) bastante instrutiva. Seu assunto é a rebelião dos trabalhadores têxteis e camponeses da Silésia, ocorrida em 1844. Foi uma rebelião espontânea, desorganizada, expressão do desespero dos famintos e miseráveis que foram facilmente massacrados pelo exército. Numa primeira indicação de que Hauptmann queria escrever um drama sobre esse assunto, a peça é dividida nos cinco atos da tragédia clássica. Mas não são atos o que temos aqui, pois essas unidades não têm o encadeamento causal que o drama exige. Seu nome técnico é quadros, que nessa peça têm encadeamento temático.

$\mathrm{O}$ primeiro quadro mostra duas coisas em contraste e em relação: a miséria e a exploração dos tecelões e os patrões às voltas com as oscilações do mercado em fase de modernização tecnológica. No segundo, uma cena da vida privada miserável, a rebelião é anunciada pela canção dos tecelões. O terceiro quadro mostra os incidentes numa taberna - comentários dos acontecimentos locais e "nacionais" - que são interrompidos pela própria rebelião, já em andamento. Indicando simultaneidade parcial com esses incidentes, no quadro seguinte o jantar da casa burguesa também é interrompido pelos rebeldes. A casa é invadida e destruída. No quadro final, voltamos à cena do segundo, mas agora o que está em andamento é o massacre dos rebeldes. Uma bala perdida mata o único personagem contrário à rebelião por acreditar na solução pacífica dos conflitos.

Nem é preciso dizer que só no primeiro quadro e em parte do quarto o diálogo mantém alguma semelhança com o diálogo dramático. Afinal, no primeiro, os trabalhadores estão negociando o valor do produto do seu trabalho ou as quantidades de tecido (e perdem). No início do quarto quadro, a família burguesa e seus amigos conversam sobre a vida, o regime político e outras amenidades, mas em seguida a canção dos tecelões acaba com aquela paz confortável. Nas demais situações sua função básica é épica: ou relato e comentário de acontecimentos do passado, ou descrição de acontecimentos do presente que se passam fora da cena. Hauptmann lançou mão da teicoscopia, a técnica considerada própria para aque- 
les acontecimentos que, por suas dimensões épicas (como é o caso da rebelião), dificilmente podiam ser encenados segundo as convenções do drama.

Esse esforço de Hauptmann acabou involuntariamente dando forma no teatro à luta de classe propriamente dita. Como se sabe, o diálogo é um dos bens mais preciosos do drama burguês. Mas a sua viabilidade cênica depende da presença de personagens livres e iguais (homens burgueses) em conflito. Em Os tecelóes temos um confronto de classes, ambas tratadas como coletivos, em sinal de respeito por parte do artista a seu material e à verdade histórica. Mas sendo o diálogo o único tipo de discurso que o drama reconhece como legítimo, ele teria que ser o veículo predominante do assunto. Mas já vimos que a partir do segundo quadro essa função passou a ser desempenhada também pela canção dos tecelões (uma só voz, porém coletiva). Tecnicamente não chegou a haver disputa entre diálogo e canção até o quarto quadro pois, a cada aparecimento da canção, o diálogo lhe cedeu o lugar. Mas no quadro da rebelião propriamente dita o diálogo permaneceu em cena, assim como os burgueses acuados. A família burguesa não tinha como resistir ao ataque, mas permanecendo em cena o diálogo também resiste. Só que esvaziado de função dramática e desempenhando a função épica de informar à plateia sobre os avanços dos rebeldes. No segmento final, após um instante em que o palco fica vazio, a multidão o invade.

Há, portanto, perdas e danos de ambos os lados: se o diálogo perdeu a sua função, o que não é pouca coisa, a rebelião ficou fora de cena, o que também significa uma perda apreciável. Mas o valor histórico e estético dessa peça está nisso mesmo - para além das questões levantadas por Peter Szondi e Anatol Rosenfeld em análises muito mais minuciosas. Nas mãos de Hauptmann ficou evidenciado, para além de qualquer dúvida, o compromisso do drama e suas categoriais formais com a burguesia. A classe trabalhadora, se quiser se ver no teatro, será obrigada a forjar seus próprios meios de expressão, assim como fez a burguesia no século XVIII. É por esse feito que a experiência da dramaturgia naturalista, como já disse Brecht, necessariamente deve figurar como o primeiro capítulo do teatro dos trabalhadores. E Os tecelões de Hauptmann, exatamente pelos problemas que evidencia, entrará nessa história como a sua primeira obra-prima.

Mesmo correndo o risco do excesso, vale a pena acrescentar que esse é o principal motivo por que o naturalismo (não só no teatro) é tão maltratado nas histórias convencionais da literatura, da arte e sobretudo do teatro.

\section{Strindberg e a superação do naturalismo no drama}

Ainda não existem os estudos necessários ao conhecimento adequado do movimento naturalista nem mesmo nos principais centros onde ele se desenvolveu - Paris, Berlim, Londres, Dublin e Moscou. As razões para esse desastre cultural podem ser resumidas em uma só proposição: as derrotas que os trabalhadores sofreram ao longo desse século, começando logo após a Revolução de Outubro, respondem pela progressiva incapacidade desses mesmos trabalhadores defenderem os seus interesses também no plano da cultura. E se nós não o fizermos não será o inimigo a fazê-lo. 
Apesar disso, é possível conceituar o naturalismo como a experiência teatral na qual pela primeira vez os trabalhadores se viram nos palcos como classe. Os tecelões é apenas uma dentre as inúmeras peças escritas e encenadas ou censuradas no período. Para dar um exemplo não muito distante, o romance Germinal de Zola teve censurada uma adaptação para teatro na mesma época. Do ponto de vista da dramaturgia, o recorte que interessa aqui, foi com o naturalismo que se explicitaram as razões de classe das incompatibilidades entre o drama como forma e as lutas dos trabalhadores como assunto.

Mesmo os dramaturgos que não estavam minimamente envolvidos com as lutas dos trabalhadores, caso de Strindberg, tinham preocupações que, levadas ao teatro, também se mostravam incompatíveis com a forma do drama. Por isso mesmo a sua obra só encontrou o caminho do palco pelas mãos de encenadores naturalistas como Antoine ou de empreendimentos desde logo inspirados na luta contra teatro livre, como foi o caso do L'Oeuvre de Lugné-Poe.

Senhorita Júlia (1888), encenada por Antoine, faz parte da família naturalista e ainda está muito próxima da peça-bem-feita, mas tem duas qualidades que interessam aqui. A primeira lhe é extrínseca, pois se trata do prefácio (publicado por Antoine no programa do espetáculo) no qual Strindberg mostra o grau de consciência dos artistas de então sobre a necessidade de se inventar novas formas. A segunda, paradoxalmente inspirada na paranoia misógina de Strindberg, acrescenta uma nova explicitação do caráter machista e de classe da ideia de liberdade, ou livre iniciativa, que nessa peça aparece sob a temática do assédio sexual (no bom sentido).

Depois dos manifestos de Zola, o prefácio da Senhorita Júlia é o documento mais importante da geração naturalista. Embora não chegue a ter o mesmo estatuto do prefácio de Victor Hugo ao Cromwell, com ele estabelece um diálogo relevante. Victor Hugo defende com grande empenho o direito do artista de transitar pelos vários gêneros segundo as exigências da matéria. Strindberg radicaliza a ideia de que gêneros e formas têm vigência histórica e, como tudo o mais, envelhecem e morrem. Mas, enquanto não morrem, constituem obstáculo à apresentação de novos conteúdos. Por isso ele considera morto o teatro em países como a Inglaterra e a Alemanha, enquanto em outros, como na Suécia, gente como ele pensou ser possível criar o novo drama preenchendo as velhas formas com o conteúdo dos novos tempos (suas palavras, literais). Senhorita Júlia seria um exemplo dessa tentativa, na qual a forma já sofreu algumas modificações importantes. Por exemplo: seus personagens não têm caráter no sentido valorizado pelo drama, porque ele não acredita na "imobilidade da alma", ou fixação de temperamento, que a ideia de caráter pressupõe. De acordo com isso, seus personagens seriam mais bem descritos como febrilmente histéricos, vacilantes e fragmentários, mais de acordo com a época de transição em que vivem. Quanto ao diálogo, Strindberg, por assim dizer, confessa ter rompido com a tradição na qual os personagens se comportam como catequistas fazendo perguntas tolas para receberem respostas inteligentes. E, no plano estrutural, Strindberg aboliu a divisão em atos.

Como não é o caso de reconstituir aqui a iluminadora análise que ele faz de sua própria peça, nem suas críticas bem-humoradas aos costumes e convenções teatrais ainda em vigor, encerremos esse passeio por seu prefácio com a metáfora bíblica que sintetiza o maior problema do teatro de seu tempo e que alguns anos 
depois ele mesmo contribuiu para solucionar: "não temos ainda novas formas para os novos conteúdos, e o novo vinho fez explodir as garrafas velhas". ${ }^{11}$

Como Senhorita Júlia apresenta características de transição semelhantes às que vimos em Ibsen e Tchekhov, vamos restringir aqui o seu exame ao fio principal do enredo que, mesmo constituindo uma ação dramática, produz uma saborosa e significativa inversão de seus pressupostos. Reduzido ao essencial, o caso aqui é que Júlia tem forte atração sexual por Jean, um criado cujos atributos físicos justificam-na inteiramente. Os obstáculos à realização desses desejos (que têm alguma reciprocidade, independentemente de motivações) são naturalmente de classe. Mas, transformando o obstáculo em vantagem, é Júlia quem toma a iniciativa do assédio e, numa sutil guerra de trincheiras, vai quebrando as resistências do atraente criado até conquistar seu objetivo. Essa conquista por certo tem um preço: primeiro a relação senhor-escravo se inverte, e, no desfecho, induzida por Jean, Júlia paga com a própria vida pela transgressão.

Aqui interessa a fase ascensional da curva dramática da trajetória de Júlia, também compreensível por ser seu criador um sueco que conheceu pessoalmente o processo feminista de conquista de muitas liberdades, incluindo a sexual, como se sabe. Júlia pode tomar, e toma, a iniciativa porque na ausência do pai é a "senhora do castelo", mesmo que temporariamente. Para o próprio Strindberg, esse comportamento é privativo dos homens e por isso ele define Júlia como uma semimulher. Em suas palavras, ela é um tipo moderno "que está lançando para a frente, que hoje em dia se vende em troca de poder, de títulos, de distinções, de diplomas, assim como estava acostumada a vender-se por dinheiro". ${ }^{12}$ Isso é o que pensa o homem Strindberg. Mas o artista mostrou com muita clareza (e o homem não percebeu) que há uma determinação de classe no comportamento tido por masculino. O teorema da primeira parte da peça demonstra que, se a personagem fizer parte da classe dominante, mesmo sendo mulher, a ela também estão abertos os caminhos da livre iniciativa, ou da liberdade, como preferem os poetas e filósofos. A segunda parte, em que Júlia paga com a vida pela transgressão, corre por conta dos valores assumidamente misóginos do dramaturgo. Mas, independentemente disso, ele acrescentou ao repertório do teatro naturalista um ingrediente importante da ampla agenda das reivindicações feministas.

Se não tivesse ultrapassado esse ponto, Strindberg seria apenas mais um dos dramaturgos naturalistas, talvez nem tivesse entrado para a história. Seu lugar na história do teatro moderno se deve às experiências mais radicais que realizou no plano da forma, na última fase de sua vida: coerente com a metáfora do vinho que explodiu a garrafa velha, no ano de 1898, após outras experiências bem e malsucedidas, Strindberg finalmente deu com a forma que pavimentou o caminho por onde passou o teatro do século XX, em particular o expressionista e o épico.

Entre as convenções do drama, uma em especial se lhe apresentava como obstáculo: a objetividade da forma, ou a impossibilidade de tratar da interioridade dos

${ }^{11}$ August Strindberg, Senhorita Júlia, Rio de Janeiro, Ediouro, s. d., p. 18.

12 Idem, ibidem, p. 23. 
personagens, como faz o romance, na medida em que a forma só reconhece aquilo que se passa na esfera das relações inter-humanas, cujo veículo é o diálogo. $\mathrm{Na}$ peça A mais forte, Strindberg já experimentara a forma do monólogo encenado como falso diálogo (só um personagem fala, como fará Cocteau muito mais tarde em $O$ belo indiferente), mas não era isso o que procurava. O pai, anterior a Senhorita Júlia, foi uma tentativa inteiramente incompreendida de introduzir o foco narrativo no drama. É então que em 1898, em Rumo a Damasco, os dois problemas foram resolvidos pelo resgate de uma das formas do teatro medieval, o drama de estações. Como indica o conceito, a matriz dessa forma é o teatro processional, ou mais simplesmente a procissão em que se rememora a Via Sacra, na qual cada estação reconstitui um episódio do último dia do Cristo, do palácio de Pilatos ao Calvário.

Rumo a Damasco é uma trilogia cujas duas primeiras partes ficaram prontas em 1898 e a terceira, em 1904. O título remete à história da conversão de Saulo de Tarso e é de conversão mesmo que a obra trata. Limitando-nos à primeira etapa desse tríptico monumental (que estreou em Estocolmo em 1900 e na França só em 1949), a primeira coisa que salta aos olhos é a combinação da estrutura em estações (quadros) com a divisão em cinco atos (inteiramente desnecessária, como se pode imaginar: a peça em quadros está nos antípodas da tragédia neoclássica).

Os quadros se sucedem num movimento de ida-e-volta perfeitamente simétrico. A ida começa numa esquina, passa pela casa de um médico, um quarto de hotel, praia, estrada, desfiladeiro, cozinha de uma casa na montanha, quarto nessa mesma casa e culmina num sanatório. Essa é a nona estação, a partir da qual dois (por assim dizer) personagens, Desconhecido e Mulher, retornam até chegar novamente à esquina inicial, num total de dezessete estações (três a mais que a Via Crucis original). Desconhecido e Mulher desenvolvem uma problemática relação amorosa, marcada por infidelidades, problemas econômicos, psicológicos e rejeição social (estão impedidos de legalizar a união). Ao mesmo tempo ambos são reciprocamente estímulo e obstáculo, conhecimento e ignorância, desdobramento psicológico e espelhamento, identificação e estranhamento. O clímax, se assim se puder chamar, é um colapso nervoso do Desconhecido que recebe tratamento num sanatório. O caminho de volta é uma peripécia para os que acreditaram na alusão à conversão de São Paulo: aqui o autoconhecimento, ou a descoberta da "verdade", ou cura, na opinião dos médicos, não resulta em mudança de comportamento, até porque os problemas objetivos (falta de dinheiro, especialmente) continuam irresolvidos. Só na cena final do último quadro teremos uma espécie de promessa de conversão, quando a Mulher convence o Desconhecido a entrar numa igreja.

O exame de todas as questões discutidas pela peça nos levaria longe demais. Mas para que se tenha uma ideia, basta enumerar as seguintes: problemas de um escritor em crise com seus editores que se recusam a lhe fazer adiantamentos, discussão dos métodos de educação dos filhos, busca de identidade jamais encontrada, blasfêmia explícita inspirada em textos do Deuteronômio (especificamente: as maldições de Moisés), métodos convencionais e heterodoxos de tratamento psiquiátrico e assim por diante.

O que realmente interessa nesta peça de Strindberg, e já foi destacado nas análises de Peter Szondi, é a descoberta (ou redescoberta) de uma forma teatral épica em 
condições de permitir a encenação daquilo que mais tarde veio a chamar-se "dramaturgia do ego", na qual não se tem mais diálogos, pois não há mais personagens. O que se tem é o sonho (ou pesadelo) de um único personagem (nesse caso, o Desconhecido) no qual todos os demais são suas próprias emanações, ou projeções. Para dizer o mesmo em outras palavras, a partir de Rumo a Damasco, tudo em Strindberg passa a ser função de um eu central, ou seja, um narrador. O texto passa a ser na verdade monólogo (com discurso indireto livre, apenas convencionalmente distribuído entre personagens que só aparentemente dialogam) no qual se assiste à encenação de episódios (quadros) da vida psíquica encoberta (ou revestida) de acontecimentos da esfera das relações inter-humanas. Essa revelação é ilimitada: não respeita as convenções de tempo, espaço, verossimilhança, valores consagrados, nada - exatamente como no inconsciente a que se refere Freud em sua Interpretação dos sonhos, que tem praticamente a mesma idade dessa peça, e não por coincidência.

Como resultado dessa estratégia (monólogo, estações), desapareceram as três unidades (ação, tempo e lugar) do drama tradicional e elas foram substituídas pela "unidade de personagem", que entretanto nem ao menos tem identidade. A lei da causalidade, determinante da unidade de ação, é substituída pela sequência solta, por fragmentos cujas ligações deverão ser identificadas por meio de categorias do repertório da crítica literária como os expostos por Freud no livro citado: condensação, fusão, metáfora, metonímia e assim por diante. Sem exagero, pode-se dizer que com Strindberg está tecnicamente consumada, também na dramaturgia, a liberdade de trânsito por todos os gêneros.

Em 1902, Strindberg escreveu $O$ sonho, que já explicita no título a referência ao modo como a estruturou. A novidade aqui, em relação ao drama de estações, é a materialização de um narrador (cuja ausência até hoje confunde intérpretes de Rumo a Damasco), que o próprio dramaturgo não reconheceu como tal, embora não lhe faltem antecedentes, na figura dos compadres do teatro de revista ou dos raisonneurs do teatro realista francês. A prova técnica do não reconhecimento do narrador (responsável pela consistência do foco narrativo e da própria narrativa como um todo) é a sua morte no terceiro ato, uma vez que ele apareceu sob a máscara de personagem dramática e essa morte compromete a consistência da peça como um todo.

Avaliando esse resultado, Peter Szondi observa que, enquanto em Ibsen a personagem dramática tinha que morrer porque faltava às peças um narrador épico, o primeiro narrador de Strindberg morreu por não ter sido reconhecido como tal. É por isso que, mesmo tendo encontrado a forma épica no drama de estações ou na estrutura do sonho para a temática épica que o século XIX já vinha apresentando havia tempo, Strindberg permanece no limiar do teatro moderno. Para o que nos interessa agora, por ter encontrado a forma épica da "dramaturgia do ego", ele é o elo com o teatro expressionista.

\section{Georg Kaiser e Ernst Toller: o expressionismo no teatro}

Uma vez que a primeira geração expressionista, anterior à Primeira Guerra Mundial, não avançou de um ponto de vista formal sobre as experiências de Strindberg, aqui vamos nos concentrar na segunda, a do entreguerras que, sem 
abandonar a estrutura do sonho, procurou romper com os limites do subjetivismo que marcou Strindberg e discípulos.

Mas, para fazer justiça ao primeiro expressionismo, cabe registrar que foram esses dramaturgos que seguiram o conselho da Mãe, personagem de Rumo a Damasco. Essa, no quadro/estação que precede o colapso nervoso do Desconhecido, dá-lhe o seguinte conselho: "você deixou Jerusalém e está na estrada de Damasco. Vá pelo mesmo caminho por onde veio. Plante uma cruz em cada estação, mas pare na sétima. Não precisa sofrer as catorze como ele". ${ }^{13}$ O próprio Strindberg ultrapassou até mesmo as catorze estações, mas os primeiros expressionistas ficaram nas sete, que se transformaram numa espécie de marca registrada da estrutura épica de suas peças.

\section{Antecedentes históricos}

Para entender o teatro da segunda geração expressionista é indispensável um conhecimento engajado da história alemã desde o final do século XIX até a proclamação da República de Weimar, quando a experiência se generalizou e expandiu.

O principal "personagem" dessa história é o Partido Socialdemocrata Alemão (Sozialdemokratische Partei Deutschland - SPD) que conquistara a legalidade no final da década de 1880 e no início do século XX veio a constituir o maior partido da classe trabalhadora, com número de parlamentares no Reichstag capaz de decidir votações (maioria). Uma das formas de luta desse partido se desenvolveu no "front" cultural, pois seus militantes e dirigentes sabiam muito bem do valor da Kultur naquele país, por eles definida como importante campo de luta. Por isso mesmo a Freie Bühne (Cena Livre), fundada por Otto Brahm inspirado em Antoine, em pouco tempo se viu obrigada a debater e votar a proposta de vinculação ao SPD. Com a vitória da facção favorável, isto é, dos militantes do SPD na Cena Livre, é criada a Volksbühne (Cena do Povo). O resultado foi a multiplicação dos grupos de teatro por toda a Alemanha, com o apoio da poderosa estrutura partidária e sindical do SPD. Segundo Anatol Rosenfeld, quando Hitler chegou ao poder em 1933, só em Berlim a Volksbühne contava com mais de cem mil militantes (ou sócios). ${ }^{14}$

Atalhando um pouco essa história, sabe-se também que em agosto de 1914, quando o Kaiser solicitou ao Reichstag a aprovação dos créditos necessários para declarar guerra à França, o SPD tinha deputados em número suficiente para barrar a proposta. Para escândalo dos socialistas do mundo inteiro, em particular Lenin, que por isso mesmo rompeu com a Segunda Internacional, os deputados socialistas, com louváveis exceções como Karl Liebknecht, votaram a favor dos créditos de guerra. E, uma vez enredados nessa lógica, votaram também a favor das leis de exceção que, entre outras providências, permitiam prender militantes pacifistas do próprio SPD por crime de alta traição, como aconteceu com Rosa Luxemburg.

\footnotetext{
${ }^{13}$ August Strindberg, "Rumo a Damasco", in —. Théatre complet, Paris, L'Arche, 1983, v. 3, p. 209.

${ }_{14}$ Anatol Rosenfeld, Teatro alemão, São Paulo, Brasiliense, 1968, p. 122. Nosso mestre lembra ainda que, encerrado o pesadelo hitlerista, a organização renasceu dos escombros alemães e, nos anos 60 do século XX, já contava com cerca de 100 associações e mais de 500 mil sócios.
} 
É impossível supervalorizar o efeito desse desastre político sobre os socialistas, em geral, e os militantes da Volksbühne, em particular. Mas, para além do efeito psicológico, a guerra propriamente dita se encarregou de dar fim à própria vida de quase todos eles: poetas, dramaturgos, atores e diretores.

Outro acontecimento, que em alguma medida reverteu a expectativa da esquerda alemã, foi a revolução na Rússia em outubro de 1917. Especialmente porque o tratado de paz assinado em separado pelos bolcheviques foi fundamental para determinar o fim da guerra. Muitos veteranos, entre os quais Piscator, voltaram das trincheiras dispostos a repetir o feito soviético na Alemanha.

Como, nesse meio tempo, a esquerda do SPD já fundara o Partido Socialdemocata Independente da Alemanha (Unabhängige Sozialdemokratische Partei Deutschlands - USPD) e a Liga Espartaquista, que em seguida (1918) formaria o Partido Comunista da Alemanha (Kommunistische Partei Deutschlands - KPD), mal assinado o Tratado de Versalhes, começa a revolução em Berlim, Munique e demais centros operários da Alemanha. Nos meses que vão de dezembro de 1918 a maio de 1919, temos um rápido processo no qual o Kaiser abdica, é proclamada a República em Weimar (porque em Berlim havia uma revolução nas ruas), os socialistas assumem o poder republicano e tratam de massacrar a revolução massacre cujo ponto alto certamente é o assassinato de Rosa Luxemburg e Karl Liebknecht (em janeiro). Munique foi o último reduto revolucionário a cair (em maio) sob os ataques dos freikorps (uma espécie de esquadrão da morte), que mais tarde vieram a integrar as SS de Hitler.

Depois de instaurada a "paz de Weimar", assistiremos ao grande surto do segundo expressionismo em todas as artes, mas com especial destaque no teatro e no cinema, gêmeos fraternos.

\section{Georg Kaiser}

Como já ficou dito, a primeira geração do teatro expressionista dera continuidade à "dramaturgia do ego" de Strindberg. Aproveitando-se do repertório já consolidado, sobretudo a estrutura de sonho-pesadelo, De manhã à meia-noite, de Georg Kaiser (encenada em Frankfurt em 1917), dá um passo adiante no plano do conteúdo, em relação aos personagens mais abstratos e relativamente sem identidade da geração anterior. O protagonista-narrador que tem um pesadelo é um bancário (caixa) e como tal é designado. Isto é: começam a interessar as determinações de classe das experiências. O sonho se desenvolve em sete estações: no primeiro episódio, ele é uma espécie de robô que trabalha enjaulado em seu guichê; depois de dar um desfalque no banco, num campo coberto de neve, interpreta como a morte uma figura formada pela neve depositada sobre uma árvore; mais adiante aposta nas corridas de cavalo, onde burgueses (de cartola) também agem como autômatos; num cabaré, uma das bailarinas tem perna-de-pau, outras caem de bêbadas e outras se transformam em bruxas assustadoras; por fim ele acaba se suicidando.

O interesse dessa peça é sua ambiguidade: lida (ou encenada) segundo as convenções realistas, ela também faz sentido, embora perca muito de seu conteúdo. Veja-se, por exemplo, a síntese de um leitor simpatizante, mas desavisado: De manhã à meia-noite é a sombria história de um bancário cuja necessidade de se 
libertar da futilidade da civilização moderna o leva ao suicídio. ${ }^{15}$ Esse crítico não percebeu que estamos diante de um pesadelo que demonstra ao infeliz sonhador as seguintes verdades: primeiro, que não há saída individual para a prisão em que se encontram os trabalhadores, mesmo os dos estratos superiores; e segundo: a saída mágica (desfalque), na melhor das hipóteses, leva a participar da vida dissipada e sem propósito da burguesia (jogo e diversão) que no fim das contas é o espelho - só na aparência desejável - da vida de autômatos que levam os trabalhadores. Como se vê, a Escola de Frankfurt não caiu do céu, pois aqui já se encontram os mais importantes temas dos melhores críticos da indústria cultural.

Assim como no caso do naturalismo, a experiência expressionista passa necessariamente pela encenação. E assim como as propostas de Antoine ainda constituem verdadeiro desafio para encenadores exigentes (Stanislavski será tratado em capítulo à parte), as dos diretores e cenógrafos expressionistas constituem referência obrigatória para o teatro exigente até hoje. Com as peças e as recomendações do próprio Georg Kaiser, as seguintes conquistas se consolidaram, ao menos na Alemanha: cenários abstratos, indeterminados, distorções e outros recursos capazes de sugerir atmosfera de pesadelo; poucos adereços, o estritamente essencial (como cartolas para burgueses), com sugestões simbólicas; como os personagens são também abstratos e representam grupos sociais (Kaiser chama-os de figuras), os atores devem preferencialmente atuar de modo grotesco, suas características devem ser enfatizadas pelos adereços, máscaras ou maquiagem; as cenas de multidão (também despersonalizadas) devem obedecer a movimentos rítmicos e mecânicos, cuidadosamente coreografados; como o diálogo é fragmentado (assim como a ação é dividida em episódios), os atores devem desenvolver um estilo telegráfico de interpretação, acompanhando o espírito do texto; enfim, como se pode ver nos filmes expressionistas, o estilo de interpretação adotará inclusive critérios musicais, sobretudo os relativos a ritmo e andamento (há uma forte preferência pela rapidez frenética e pelo staccato). ${ }^{16}$

\section{Ernst Toller}

Como ficou sugerido, uma das operações de Georg Kaiser no plano do conteúdo foi reduzir o grau de abstração do personagem herdado de Strindberg, ao adotar determinações de classe a partir das quais faz sentido a crítica aos rumos da sociedade moderna. Já Ernst Toller, um veterano da revolução massacrada em 1919 (foi preso e condenado a vinte anos por crime de "alta traição"), tratou de aprofundar essa orientação mais claramente política do segundo expressionismo.

Ainda na prisão, Toller escreveu As massas e o homem, encenada pela Volksbühne de Nuremberg em 1920 e pela de Berlim em 1921. Trocando essas informações em miúdos, o público a que se dirigia a peça era constituído majoritariamente por veteranos da revolução, como o próprio autor. Isso explica, por um lado, o sucesso

${ }^{15}$ Apud J. L. Styan, Modern drama in theory and in practice 3. Expressionism and Epic Theatre, Cambridge, Cambridge University Press, 1981, p. 48-50.

${ }^{16}$ De acordo com o resumo do mesmo Styan, Modern drama in theory and in practice 3, op. cit. 
absoluto da peça e a projeção de Toller a maior dramaturgo alemão da era pré-brechtiana. Por outro lado, explica também a leitura inteiramente equivocada da crítica e do público nos países onde a peça foi encenada, sempre com muito sucesso, como é o caso da Inglaterra e dos Estados Unidos (país para onde seguiu o dramaturgo exilado). Esse fenômeno se verificou ainda na Alemanha, uma vez que a peça acabou sendo vista (e criticada) também pelos inimigos de classe. A esses o próprio dramaturgo respondeu, no prefácio à segunda edição da peça, nos seguintes termos:

pode ser que, para o crítico ligado à burguesia, que não conhece os proletários como nós [...], a formulação das lutas ideológicas mais significativas e revolucionárias, que mexem com os homens dos pés à cabeça, pareça uma simples figura de retórica ou uma frase de editorial. Mas de uma coisa não há dúvida: o que, tanto na arte quando na 'vida real' soa ao burguês como uma discussão tola em torno de palavras sem maior significado, para o proletário é a expressão mais pura da sua tragédia e da sua aflição. Por outro lado, o que o burguês interpreta como um pensamento altamente profundo e filosófico, a própria essência da efervescência intelectual, para o proletário não diz rigorosamente nada. ${ }^{17}$

Toller há de ter se indignado com o profundo grau de ignorância e insensibilidade, inclusive auditiva, em relação a uma peça que tentou simplesmente reconstituir, por meio das mais eloquentes estratégias discursivas, a história da revolução então recente. Mas, com a distância histórica, é forçoso admitir que seria demais pedir a críticos, provavelmente ignorando até o assassinato de Rosa Luxemburg, que identificassem no enfrentamento entre as lideranças revolucionárias dos trabalhadores os movimentos da classe desde a luta pacifista (clandestina) até a derrota e os debates em torno das estratégias de sobrevivência então em andamento.

Para remediar um pouco esse estado de opacidade em que o texto mergulhou desde que se viu separado de seus originais e legítimos interlocutores, comecemos pela descrição de sua estrutura e principais figuras (para já adotar a terminologia de Georg Kaiser).

Dividida em sete episódios, As massas e o homem apresenta uma novidade que indica a tendência a abandonar o campo da subjetividade, num retorno à objetividade, mas em nova chave, pois esse retorno traz consigo as conquistas formais do momento anterior, como o foco narrativo e o clima de pesadelo. A novidade é a alternância entre os planos do sonho e da realidade: os quadros ímpares estão na realidade e os pares são pesadelos, ou sonhos muito reveladores devidamente indicados como tais. Mas o dramaturgo recomenda ao encenador que procure, no plano da interpretação e demais recursos cênicos, confundir as fronteiras entre sonho e realidade, evitando sobretudo os ambientes realistas. Nessa moldura, o protagonista é o processo histórico alemão no período que vai do final da guerra ao massacre da revolução. O que vemos por meio das figuras são seus diversos agentes. A primeira estação mostra o processo vivido por uma Mulher (assim designada) que abandonou um casamento burguês para aderir à causa pacifista dos trabalhadores, enfrentando duas consequências de igual importância: foi denunciada pelo marido, alto

${ }^{17}$ Ernst Toller, "Prefácio a As massas e o homem", in Ulrich Merkel (org.) Teatro e política. Expressisonismo, Rio de Janeiro, Paz e Terra, 1983, p. 29. 
funcionário do Estado, por crime de alta traição, e ao mesmo tempo acaba sendo aclamada como líder pelos trabalhadores mobilizados. Esse seu movimento não é inteiramente radical, pois ela continua presa ao marido, sobretudo no plano sexual. O segundo quadro é o maior dos pesadelos: na bolsa de valores, os banqueiros disputam as ações da indústria bélica que a certa altura começam a cair (isto é, a guerra está próxima do fim); numa derradeira tentativa de prolongá-la, e para tanto infundir ânimo nos soldados, os concorrentes se unem para impor ao Estado a criação de um imenso bordel destinado aos soldados. E para dar início ao levantamento de fundos, organizam um baile no qual já começam a arregimentar as prostitutas. No terceiro quadro, uma assembleia de trabalhadores mostra como foi rápida a transição da luta pacifista para a revolução. No início prevalecem as intervenções em defesa da proposta de greve dos trabalhadores da indústria bélica para forçar o fim da guerra. A Mulher lidera essa tendência até começar a ser enfrentada pelo Anônimo que propõe revolução. No desfecho, o coro toma a palavra: venceu a proposta de revolução. O quadro seguinte é o sonho da Mulher, no qual a revolução é vitoriosa e ela tem que enfrentar suas consequências: seu marido é preso e condenado à morte; intercedendo sem sucesso em seu favor, ela pede para ser executada junto com ele. No quinto quadro, temos a revolução propriamente dita. Estamos no quartelgeneral dos revolucionários, onde chegam sucessivas notícias de derrotas e as tendências representadas pela Mulher e pelo Anônimo agora se confrontam sobre questões como indivíduo versus massa, luta armada versus não violência, e assim por diante. São as polêmicas entre os leninistas e os luxemburguistas. Estes últimos são contra a violência por princípio, não aceitando nem mesmo a violência revolucionária, contra a qual defendem os direitos individuais; e aqueles defendem a luta armada, falam em nome da massa, que acreditam ser capazes de conduzir. No final, a revolução foi derrotada, os dirigentes estão cercados e se entregam cantando $A$ internacional. No quadro seguinte, há outro sonho da Mulher: numa jaula em um sanatório, ela é observada por um enfermeiro e está sendo processada, isto é, tratada. Nesse "tratamento", investigam-se vários tipos de culpas e quando todos concluem que o maior culpado é Deus, ela recebe alta. No quadro final, a Mulher está presa, foi condenada à morte e aguarda a ordem de execução. Seu companheiro de luta e adversário teórico, o Anônimo, consegue infiltrar-se na cela e apresenta-lhe um plano de fuga, uma vez que seus companheiros de partido dispõem de um esquema eficiente. Ela o recusa porque não aceita métodos violentos e o plano inclui a necessidade de matar um guarda. Assim sendo, ela é mesmo executada.

Pelo exposto, dá para perceber que há muito o que discutir sobre essa peça em diversos planos. Para o que interessa agora, basta esclarecer dois pontos: formalmente, a Alemanha já encontrou a forma do teatro épico; criticamente, dadas as condições de recepção dessa peça, já referidas, ela foi transformada numa espécie de suma do teatro expressionista, e como tal é conhecida, especialmente nos países onde foi encenada. No entanto, por maiores que sejam a simpatia e o interesse que a cercam, ela teve seu conteúdo inteiramente esvaziado; as referências a seu respeito se prendem estritamente a seus "feitos" cênicos e de interpretação (individuais e ensembles). Uma síntese desse esvaziamento está cifrada em uma referência inglesa ao espetáculo assistido na Alemanha, segundo a qual, na cena da prisão dos dirigentes revolucionários, esses teriam cantado A marselhesa. Para 
quem conhece história desde 1789, confundir A Internacional com A marselhesa, e numa peça que tem como protagonista a revolução proletária, esse não é um equívoco de pequenas consequências.

\section{Piscator e Brecht: formas do teatro político}

\section{Piscator}

Erwin Piscator serviu na guerra como soldado e viveu todo o seu horror nas trincheiras. Nessa situação, organizou um grupo de teatro que tinha a função de distrair os soldados. Após o tratado de paz com a Rússia bolchevique, teve oportunidade de se confraternizar com os soldados russos com os quais tomou conhecimento da forma de teatro criada pelos revolucionários, o agitprop, que aqui referiremos simplesmente como teatro de agitação. De volta a Berlim, tratou de adaptar para a situação alemã, pré-revolucionária, aquele modelo relativamente simples de intervenção estético-política: um curto esquete, de duração entre dez e quinze minutos, sobre assunto da ordem do dia, era preparado e apresentado nas ruas, em portas de escolas e fábricas, em assembleias de trabalhadores, comícios e demais manifestações políticas. Os inúmeros grupos contavam com elenco relativamente pequeno, não trabalhavam com cenários nem figurinos, mas apenas com adereços fáceis de transportar (e de carregar em caso de necessidade de fugir da polícia, ocorrência comum), assim como procuravam combinar a interpretação, tão esquemática quanto a expressionista, com números musicais (de preferência coros aos quais os espectadores costumavam aderir) que iam dos hinos dos trabalhadores a paródias de canções conhecidas.

Após o massacre de 1918-1919, a modalidade naturalmente entrou em baixa e Piscator tratou de se dedicar ao teatro "convencional", isto é, profissional, vinculando-se à Volksbühne de Berlim (não podemos nos esquecer de que, com o SPD no poder, a administração dos teatros públicos alemães ficou em suas mãos). Quando começou a participar da direção do Deutsches Theatre, Piscator registrou: "pela primeira vez eu tinha em mãos um teatro moderno, o teatro mais moderno de Berlim, com todas as suas possibilidades". ${ }^{18}$ Entre essas possibilidades estava a da participação ativa do público trabalhador em todo o processo da encenação: desde a escolha do texto, passando pela produção, até o debate após as apresentações (havendo casos de interferência durante o próprio espetáculo). Piscator relata o divertido episódio ocorrido num sindicato em que, cansados de esperar pela chegada de um painel, o espetáculo foi iniciado. Quanto o painel chegou, o espetáculo foi interrompido e fez-se uma assembleia para decidir se começavam tudo de novo com o painel instalado ou continuavam do ponto em que estavam.

Como seria de esperar, Piscator levou para o teatro convencional a experiência do teatro de agitação e, entre outras, encenou em 1924 a peça Bandeiras (sobre os acontecimentos de Chicago que estão na origem das comemorações do Primeiro de Maio), na qual foram vistas todas as experiências cênicas que apontavam para o teatro épico, como os efeitos de multidão de Antoine, a rebelião que só ficou

${ }^{18}$ Erwin Piscator, Teatro político, Rio de Janeiro, Civilização Brasileira, 1968, p. 67. 
sugerida em Os tecelões, assim como as assembleias e passeatas do teatro expressionista. Novamente a crítica conservadora foi à luta. Entre outras acusações, esse espetáculo recebeu a de que não tinh a nenhuma qualidade dramática.

A polêmica sobre esse espetáculo na imprensa alemã tem interesse histórico: pela primeira vez a qualificação "épico", que até então tivera conotação negativa, passou a ser assumida como positiva. Um dos responsáveis pelo feito foi o romancista Alfred Döblin, que saiu em defesa do espetáculo com o seguinte argumento, reproduzido por Piscator no livro citado: colocando a peça num muito fértil terreno intermediário entre o romance e o drama, aposta que "será procurado pelos que têm algo a dizer e representar, e aos quais não agrada a forma empedernida do nosso drama que obriga a uma arte dramática também empedernida". O nome dessa forma, que vinha sendo procurada desde o "drama social" dos naturalistas, podia mesmo ser "épica", pois a descrevia muito bem.

\section{Brecht}

Quando Brecht entrou nessa história, portanto, até o conceito de teatro épico já estava disponível, embora ainda estivesse longe de consolidado (se é que se pode falar nisso). Tanto é assim, que seus primeiros textos teóricos, de meados dos anos 1920, ainda participam da luta pelo direito à forma e pelo conceito.

Como Piscator, Brecht também conheceu pessoalmente a guerra, embora não tivesse servido nas trincheiras. Estudante de medicina, foi recrutado como enfermeiro em 1917. O que viu, fez e entendeu no período está resumido na atroz $\mathrm{Ba}$ lada do soldado morto, em que, entre outras imagens chocantes, um médico dá o diagnóstico "está bom pro serviço" a um soldado morto, mas ainda inteiro.

Terminada a guerra, participa ativamente da vida literária, teatral e política em Munique e Augsburg, a ponto de ter sido eleito membro do Conselho (Soviet) de Trabalhadores e Soldados de sua cidade durante a Revolução. Na condição de delegado do Conselho de Augsburg, participou da República Soviética de Munique, liquidada em maio de 1919 pelos freikorps.

Suas duas primeiras peças teatrais, Baal (1918) e Tambores na noite (1920), estão nitidamente vinculadas às experiências expressionistas. Mas o assunto da comédia grotesca que é Tambores na noite é o mesmo da peça de Ernst Toller a revolução, nesse caso vista do ângulo dos sórdidos interesses de uma família pequeno-burguesa. Baal experimenta, à maneira do primeiro expressionismo, a estrutura em estações e, em relação a ela, Tambores na noite constitui um nítido recuo formal, com a estrutura em três atos e o encadeamento dramático dos acontecimentos que envolvem os personagens grotescos. Mas como as marchas e contramarchas da guerra e da revolução são o pano de fundo, esta última acaba invadindo a cena, um pouco à maneira do ocorrido em Os tecelões de Hauptmann.

As experiências seguintes mostram o dramaturgo às voltas com o programa comunista e, como as peças de Toller, também dependem da incorporação da história da República de Weimar para serem analisadas com menos parcialidade. Estamos evidentemente nos referindo às peças didáticas que só muito recentemente (anos 80), a partir dos trabalhos de Reiner Steinweg, começam a ser mais propriamente decifradas. 
A última delas é A exceção e a regra, que, por motivos enraizados na história dos últimos dias da República de Weimar (entre eles o massacre dos trabalhadores promovido pelo governo socialista no primeiro de maio de 1929), não chegou a ser encenada na Alemanha nem mesmo pelos grupos comunistas.

Sem querer forçar demais, o teorema central da peça pode ser formulado a partir da sentença de absolvição do réu: "O acusado, portanto, agiu em legítima defesa, tanto no caso de ter sido realmente ameaçado quanto no caso de apenas sentir-se ameaçado". O acusado é um comerciante que assassinou seu empregado durante a travessia de um deserto. A vítima se aproximara do patrão com um cantil para dar-lhe de beber. Seu temor era que o patrão morresse de sede, caso em que com certeza seria condenado por assassinato. Confundindo o cantil com uma pedra e certo de que o trabalhador tinha todos os motivos para atentar contra a sua vida, o comerciante atira à queima-roupa. Examinada a situação, é legítimo concluir que para o trabalhador não havia saída - estava condenado de antemão. Da mesma forma, o patrão estava absolvido de antemão e é sobre esse beco sem saída que o dramaturgo dialético espera que pensemos. Trata-se de examinar, ou pelo menos atinar com a ideia de que o Poder Judiciário é expressão em última instância do medo que a classe dominante tem dos dominados. Esse medo se exacerba quando fica evidente a violência necessária ao exercício da exploração, da qual também depende a realização de grandiosos projetos econômicos de ponta. Angustiado pelo enfrentamento com os concorrentes e se esforçando para vencê-los (ou de preferência eliminá-los), e aterrorizado pela simples ideia de que o trabalhador possa reagir a seus desmandos com violência proporcional segundo a lei de Talião, não passa pela cabeça do comerciante que o trabalhador oprimido, sabendo-se sem nenhum direito, descarta $a$ priori qualquer tipo de reação violenta. Digamos que a situação chegou ao ponto no qual não dá mais para a classe dominante confiar no poder da ideologia. Cometendo o desatino de destruir quem lhe asseguraria a vitória sobre seus concorrentes, ainda resta a esse assassino o consolo de verificar que a Justiça de Classe está a postos para ao menos evitar que lhe chegue a cobrança do preço a pagar por seu crime. Por certo não se trata de atribuir a Brecht nenhum poder premonitório. Mas não é preciso ser especialista na história do nazismo para ver que foi mais ou menos isso que aconteceu com a ascensão de Hitler, cujas providências assassinas de amplo alcance foram todas sacramentadas por uma serena estrutura judicial, como ficou amplamente demonstrado depois da guerra pelo Tribunal de Nuremberg.

Posta em perspectiva da história do teatro que aqui nos interessa, A exceção e a regra dá continuidade à discussão sobre a violência iniciada por Hauptmann e ampliada por Toller. O passo adiante de Brecht consiste em mostrar as prerrogativas legais da violência exercida pela classe dominante. ${ }^{19}$

\footnotetext{
${ }^{19}$ Suzana Mello defendeu dissertação de mestrado sobre essa peça de Brecht, na qual mostra até mesmo o diálogo crítico que o dramaturgo desenvolve com as teorias de Carl Schmitt. É de extremo interesse sua análise indireta do papel socialdemocrata na configuração dos paradoxos políticos que Brecht examina (cf. Suzana Campos Albuquerque Mello, "A exceção e a regra", de Bertolt Brecht ou a exceção como regra: uma leitura. 2009. Dissertação (Mestrado) - Faculdade de Filosofia, Letras e Ciências Humana, Universidade de São Paulo, São Paulo, 2009).
} 
Todos têm conhecimento da sanha genocida de Hitler. O que ficou restrito ao campo da esquerda foram as suas investidas contra os partidos dos trabalhadores e todas as suas organizações. Nas palavras de Eve Rosenhaft:

bares, diretórios de partidos, sindicatos, jornais, livrarias, salas de leitura, clubes, hospitais, escolas, centros de, assistência social e teatros que fizeram o tecido da cultura de Weimar foram os primeiros objetos da onda de vandalismo oficial realizada em nome da ordem, da decência pública e da economia. ${ }^{20}$

Como também se sabe, Brecht não pagou para ver: em 28 de fevereiro de 1933, dia seguinte ao incêndio do Reichstag, fugiu da Alemanha com a família. Hitler assumiu o poder nesse mesmo dia.

No exílio, Brecht escreve (ou conclui) suas obras primas, que também são as obras primas do teatro épico. Dessas cabe destacar A Santa Joana dos Matadouros que, embora escrita entre 1929 e 1930 e tendo partes apresentadas em rádio em 1932, integra esse conjunto e tem impressionante atualidade. Sobre esse ponto, basta referir a permanência em cartaz da produção brasileira da Companhia do Latão por cerca de um ano.

Conforme um crítico bem informado, Brecht pôs o capitalismo no centro dessa peça. Avançando um pouco, diríamos que ele examinou a crise de superprodução (que em 2008 voltou à ordem do dia) e seus efeitos: paralisia da produção, transformação de populações inteiras de trabalhadores em item supérfluo (excluídos, como se diz atualmente) e a necessidade de pensar na própria sobrevivência da espécie humana, ameaçada pelos exploradores da mais-valia.

A partir da produção paralisada, somos expostos a episódios que se passam na esfera da circulação - a das mercadorias encalhadas que são tanto a força de trabalho como a carne enlatada ou rebanhos inteiros. Temos ao mesmo tempo a crise de abastecimento, que em linguagem não especializada pode ser simplesmente chamada de produção da fome em escala industrial. Tudo isso se passa em Chicago, que desde o século passado concentra na bolsa de mercadorias o essencial dos negócios mundiais no ramo da agricultura. É lá que se decidem, em curto, médio e longo prazos, o destino dos produtores agrícolas de todo o mundo e a fome ou o abastecimento de populações inteiras.

Nesse quadro, em que o capital (ou "sujeito automático", segundo alguns contemporâneos de Marx) parece assumir vida própria, todos os envolvidos pela crise se comportam como baratas tontas. Ninguém entende o que se passa, aproveitadores ou vítimas; nem mesmo o partido (comunista) que deveria ter a capacidade de formular alguma estratégia de saída para os trabalhadores. Como a luta que se abre entre exploradores e explorados é vencida pelos primeiros (que apelam para a violência máxima), e como, no mesmo processo, esses encontram a saída para a sua crise (com direito a intervenção do Estado), abre-se uma situação na qual deverá ser

${ }^{20}$ Eve Rosenhaft, "Brecht's Germany: 1898-1933", in Peter Thomson e Glendyr Sacks, The Cambridge Companion to Brecht, Cambridge University Press, 1994, p. 20. 
ampliado o papel da organização religiosa, uma vez que a saída encontrada pelo capital envolve uma revolução tecnológica que deverá produzir ainda maior desemprego, mais fome e mais miséria. Por isso, Joana, que morre durante os enfrentamentos da guerra civil, é canonizada pelos capitalistas e seus aliados na imprensa.

Não se tem notícia de outra obra teatral no século XX com o mesmo grau de ambição artística e intelectual. Nessa peça, Brecht mobiliza todos os recursos da forma épica, inteiramente a serviço do conteúdo. Por isso, A Santa Joana dos Matadouros pode ser pensada como uma síntese do teatro épico moderno.

O teatro épico pode agora ser definido como a forma teatral encontrada, num processo de aproximadamente quarenta anos, por dramaturgos e encenadores de alguma forma ligados às lutas dos trabalhadores, para expor o mundo segundo a experiência dos trabalhadores.

Com Hauptmann vimos a forma do drama burguês operando como um obstáculo real para a exposição da luta ocorrida na Silésia. Ibsen questionou objetivamente a universalidade do conceito burguês de indivíduo, mostrando que ele exclui pelo menos a metade feminina da humanidade. Tchekhov mostrou que a burguesia e sua forma teatral não tinham futuro. Strindberg descobriu com o drama de estações uma forma de romper com a objetividade do drama, abrindo o caminho para o aparecimento do foco narrativo e, com ele, a possibilidade de ultrapassar as limitações da narrativa dramática, que exige entre outras determinações o encadeamento causal dos acontecimentos. As duas gerações do expressionismo consolidaram a forma épica e a segunda mostrou o seu interesse para os trabalhadores na exposição de seus próprios assuntos. Brecht constitui a síntese desse processo e por isso o conceito de teatro épico vinculou-se, com justiça, a seu nome, porque sua obra teatral foi acompanhada de uma permanente militância crítica e teórica, por meio da qual o conceito se consolidou.

Para quem se dedica ao assunto tanto tempo depois, entretanto, é bom lembrar da observação do mesmo Brecht num ensaio muito a propósito intitulado "O teatro como meio de produção": "o teatro épico pressupõe, além de um certo nível técnico, um poderoso movimento social, interessado na livre discussão de seus problemas vitais e capaz de defender esse interesse contra todas as tendências adversárias". ${ }^{21}$

Esse alerta é para introduzir o problema central do nosso tempo: depois de todas as derrotas sofridas pela classe trabalhadora ao longo do século XX, não se pode esperar que o conhecimento dessa história esteja disponível e muito menos organizado em livros. Ao contrário, em vista dos direitos do vencedor, as histórias do teatro no século XX são escritas com apoio em outros critérios e, no âmbito da forma, estão presas a inúmeras atualizações dos pressupostos do drama (já que a forma propriamente dita está inteiramente ultrapassada, mesmo no campo conservador). Com os seus pressupostos, entretanto, continuam sendo cultivadas as expectativas de ordem dramática que dão régua e compasso a críticos e historiadores, com os quais também temos muitas contas a acertar.

${ }^{21}$ Bertolt Brecht, Escritos sobre teatro, Buenos Aires, Nueva Visión, 1976, p. 135. 